\title{
Primary ovary hemangiosarcoma in a female dog
}

\section{Hemangiossarcoma primário em ovário de um cão fêmea}

\author{
Elisângela Olegário da Silva ${ }^{1 *}$; Danilo Gouveia Wasques²; \\ Carmen Lúcia Scortecci Hilst'3; Antônio Carlos Faria dos Reis \\ Ana Paula Frederico Rodrigues Loureiro Bracarense ${ }^{4}$
}

\begin{abstract}
A nine-year-old female Boxer was diagnosed with osteosarcoma in the right hind limb. During imaging exams to investigate the occurrence of metastasis, it was observed a mass in the abdominal cavity. A laparotomy was performed, and the mass was detected in the left ovary. Intraoperative fine-needle aspirates were made and showed spindle cells with moderate cellular pleomorphism and neutrophils. The cytological findings were not compatible with osteosarcoma metastasis. The mass was excised and submitted to histopathological evaluation. The microscopic examination showed a proliferation of spindle cells forming small vascular channels and a trabecular pattern interspersed by discrete to moderate collagenous stroma. The cells showed moderate cellular pleomorphism and high mitotic index. There was abundant necrosis and multifocal hemorrhage. The definitive diagnosis was hemangiosarcoma. This is a rare primary ovary tumor in dogs with just one previous report in veterinary literature. However, it should be considered as a differential diagnosis in female dogs with ovary mass.
\end{abstract}

Key words: Oncology, sarcoma, vascular origin, ovary, dog

\section{Resumo}

Um cão, fêmea, raça Boxer, com nove anos de idade foi diagnosticado com osteossarcoma no membro posterior direito. Durante a investigação de ocorrência de metástase por meio de exames de imagem, observou-se presença de uma massa na cavidade abdominal. Realizou-se laparatomia exploratória e observou-se que a massa estava localizada no ovário esquerdo. O exame citológico intraoperatório demonstrou presença de células fusiformes com moderado pleomorfismo celular e neutrófilos. Tais achados citológicos não foram sugestivos de metástase de osteossarcoma. A massa foi totalmente excisada e submetida à avaliação histopatológica. No exame microscópico observou-se uma proliferação de células fusiformes dispostas em arranjos trabeculares formando canais vasculares, entremeadas por discreto a moderado estroma colagenoso. As células mostraram moderado pleomorfismo celular e alto índice mitótico. Havia presença de necrose acentuada e hemorragia multifocal. Com base nos achados histopatológicos, o diagnóstico definitivo foi de hemangiossarcoma. Este tumor raramente acomete o ovário como sítio primário em cães e foi relatado apenas uma vez na literatura veterinária. No entanto, deve ser considerado como diagnóstico diferencial em cães fêmeas com massa em ovário.

Palavras-chave: Oncologia, sarcoma, origem vascular, ovário, cão

\footnotetext{
${ }^{1}$ Prof $^{\mathrm{a}}$, Faculdade Integrado de Campo Mourão, Campo Mourão, PR. Discente de Doutorado do Programa de Pós-Graduação em Ciência Animal, Universidade Estadual de Londrina, UEL, Londrina, PR, Brasil. E-mail: elivet02@gmail.com

${ }^{2}$ Médico Veterinário Autônomo, São Paulo, SP, Brasil. E-mail: danilogw@gmail.com

${ }^{3}$ Prof. do Dept ${ }^{\circ}$ Clínicas Veterinárias, UEL, Londrina, PR, Brasil. E-mail: chilst@uel.br

${ }^{4}$ Profs. do Dept ${ }^{\circ}$ de Medicina Veterinária Preventiva, UEL, Londrina, PR, Brasil. E-mail: reis@uel.br; ana.bracarense@pq.cnpq.br

* Author for correspondence
} 


\section{Introduction}

Primary ovary tumors are uncommon in dogs, accounting for $1.04 \%$ of all canine tumors (SFORNA et al., 2003). The low incidence is due to a large segment of dogs population that is surgically neutered in early age. A breed predisposition has not been reported and middle-age to older dogs are the most affected. The clinical signs vary, depending on the cell origin, but more commonly are associated with signs of a space-occupying mass (KLEIN et al., 2007).

Abdominal radiographs and ultrasonography, and intraoperative fine-needle aspirates are important tools to a predictive diagnosis of ovarian mass. The definitive diagnosis is obtained by histopathological examination. The complete ovariohysterectomy and a careful examination of all serosa surfaces, including the omentum and diaphragm, and removal or biopsy of any lesions suspected of metastatic disease are recommended (KLEIN, 2007).

The ovarian tumors are classified according to cell origin: epithelial (papillary adenoma, papillary adenocarcinoma, cystadenoma and undifferentiated carcinoma), germ (dysgerminoma, teratocarcinoma and teratoma) and sex cord stromal (thecoma, luteoma and granulosa cell tumor). The epithelial and sex cord stromal tumors are the most frequent in the female dog (SFORNA et al., 2003; KLEIN, 2007). Primary mesenchymal tumors in ovary can occur, but are rare (KLEIN, 2007). In veterinary literature, there is one report of an ovarian hemangiosarcoma in a female dog (SFORNA et al., 2003). Hemangiosarcoma is a malignant neoplasm that arises from the endothelial cells and when occur in visceral organs is highly aggressive with a poor prognosis due to the possibility of rupture of the tumor (GOLDSCHMIDT; HENDRICK, 2002).

The aim of this paper is to describe a case of primary ovary hemangiosarcoma in a female dog and their clinical aspects, cytological and histopathological findings.

\section{Case report}

A nine-year-old female intact Boxer dog was admitted to the Veterinary Hospital, Universidade Estadual de Londrina, Londrina/PR, Southern Brazil. The animal had a history of lameness and pain in right hind limb. The animal had a previous diagnosis of osteoblastic osteosarcoma in the femur and was submitted to investigate the occurrence of metastasis. The ultrasonography exam revealed a mass in the abdominal cavity situated in the left side between the cranial pole of the urinary bladder and the caudal pole of the kidney. A laparotomy was performed, and the mass was detected in the left ovary. Intraoperative fine-needle aspirates were done. Smears contained small number of spindled cells individualized or clustered, with indistinct cytoplasmic borders, elongated to oval nuclei, reticular chromatin and occasionally, conspicuous nucleoli (Figure 1A). Discrete to moderate anisocytosis and anisokaryosis were observed. Presence of abundant amount of blood and moderate amount of neutrophils was also verified. The cytological interpretation was atypical mesenchymal cells accompanied by neutrophilic inflammation. The mass was excised and submitted for histopathological examination.

Grossly, the mass was firm, multilobulated with reddish and blackened areas, measured $9 \times 4 \times 4$ $\mathrm{cm}$ (Figure 1B). On cut section showed blackened areas merged with reddened areas (Figure 1C). The histopathological evaluation showed a delimited, but unencapsulated mass, infiltrative and highly cellular tumor. The spindle cells formed small vascular channels and a trabecular pattern interspersed by discrete to moderate collagenous stroma (Figure 1D). The cells showed moderate anisokaryosis and 6 mitoses per 10/400 x fields. There was abundant necrosis, multifocal hemorrhage, and large amount of hemossiderophagos.

A clinical examination showed no presence of lesion, nodule or mass in the skin. The exploratory laparotomy revealed no other change in the abdomen 
beyond the ovary. The thoracic radiography was performed and no changes in organs conformation or the presence of mass were detected. Based on clinical, radiographic and histopathological findings, the definitive diagnosis was ovary primary hemangiosarcoma.

The most common presentation of the hemangiosarcoma is a multicentric disease involving the spleen, liver, lungs and right auricle of dogs (GOLDSCHMIDT; HENDRICK, 2002). Other frequent site of development is the skin (KLEIN, 2007). Cases have also been reported in bone, urinary bladder, oral cavity, uterus, retroperitoneum, left ventricle and muscle (OKSANEN, 1978; BROWN; PATNAIK; MacEWEN, 1985; ERDEM; PEAD, 2000; LIPTAK; DERNELL; EHRHART, 2004; LIPTAK; DERNELL; WITHROW, 2004). There is just one case reporting a hemangiosarcoma in the ovary of a female dog (SFORNA et al., 2003).

Clinical signs in dogs with ovarian tumors depend on the cell origin. Most epithelial cell tumors may produce malignant effusion; granulosa cell tumors, dysgerminomas and teratomas have been associated to malignant abdominal effusions (SFORNA et al., 2003). Teratomas commonly show areas of calcification that are seen on routine abdominal radiographs, whereas sex cord tumors have the ability to produce steroid hormones (THAMM, 2007). However, most ovary tumors are asymptomatic until signs referable to a spaceoccupying mass occur (KLEIN, 2007).

Dogs with visceral hemangiosarcoma may present acute weakness or collapse, but some animals present asymptomatically or nonspecific signs as anemia, lethargy, inappetance, weight loss, abdominal distension and in these cases an abdominal mass is often palpated during examination (KLEIN, 2007). In this case, the clinical signs were related to the osteosarcoma in the right hind limb and the mass in left ovary was an incidental finding. The ovarian mass was relatively small and no palpable in physical examination.
Radiographic examination or ultrasonography is important assays that contribute to the diagnosis. Animals with neoplasia were routinely submitted to these exams as a part of metastasis investigation. In this case the ultrasonography has evidenced a mass in the abdominal cavity.

Transabdominal needle biopsies of ovarian masses are not recommended due the propensity of tumoral cells (mainly of epithelial origin) to readily implant and grow on peritoneal surfaces (KLEIN, 2007). Similarly, this procedure should not be performed when visceral hemangiosarcoma is suspected, due to the risk of hemorrhage and subsequent tumor cell seeding on the peritoneum (THAMM, 2007). In the present case, the fine-needle aspirate was intraoperative and was important to the differential diagnosis of metastatic osteosarcoma in the ovary or a primary ovarian neoplasm.

The fine-needle aspirates from hemangiosarcoma may yield very few or many mesenchymal cells. Usually, an abundant amount of blood is also collected. Neoplastic endothelial cells collected from hemangiosarcoma morphologically range from apparently normal endothelial cells to large cells with marked variation in cellular, nuclear, and nucleolar size and increased nuclear: cytoplasmic ratio (TYLER; COWELL; MEINKOTH, 1999). In our case, the mesenchymal cells showed discrete cellular pleomorphism. This aspect, combined with the presence of neutrophils did not allow differentiation between neoplasia and fibroplasia. These features are commonly observed in smears of cutaneous hemangiosarcoma (TYLER; COWELL; MEINKOTH, 1999).

To obtain the definitive diagnosis, the neoformation was excised and submitted for histopathological evaluation. The histopathological findings were compatible with a well differentiated hemangiosarcoma(GOLDSCHMIDT;HENDRICK, 2002; GROSS et al., 2005). The main differential diagnose for this tumor is capillary hemangioma. In contrast to this benign tumor, the vascular spaces 
of hemangiosarcoma are not uniformly enclosed by endothelial cells. Furthermore, infiltrative tumor margins with dissection of collagen bundles, large number of blindly-ending trabeculae, frequent mitotic figures, atypical mitoses, and cellular and nuclear pleomorphism are useful indicators for hemangiosarcoma (GROSS et al., 2005).

The prognosis to ovarian neoplasms is good when single tumors are completely excised at surgery. However, if there is evidence of metastasis, the prognosis must be considered poor (KLEIN, 2007). The prognosis to visceral hemangiosarcoma is poor due their aggressive behaviour and frequent rupture of nodules and masses that can result in death of the animal (GOLDSCHMIDT; HENDRICK, 2002). In this case the animal presented a reserved to poor prognosis due the concomitant presence of two different and aggressive tumors, osteosarcoma and hemangiosarcoma. Clinical signs, laboratory and imaging exams are important tools but generally do not yield conclusive diagnoses. The histopathological examination is fundamental for the definitive diagnosis of ovarian tumors. Despite the rare presentation of hemangiosarcoma in the ovary, this should be considered in the differential diagnosis of ovarian tumors in female dogs.

Figure 1. A-Fine-needle aspirate of left ovary mass in a bitch. Spindled cells clustered, with indistinct cytoplasmic borders, elongated to oval nuclei, reticular chromatin and occasionally, conspicuous nucleoli. Giemsa, objective of 100x. B-Macroscopic aspects of left ovary mass in a female dog. Multilobulated mass with blackened areas and firm consistency. C-Macroscopic aspects of left ovary mass in a female dog. Note the blackened areas merged with clear areas. D-Microscopic findings of left ovarian mass in a bitch. The malignant mesenchymal cells formed small vascular channels and trabecular pattern interspersed by discrete to moderate collagenous stroma. H\&E, objective of 40x.

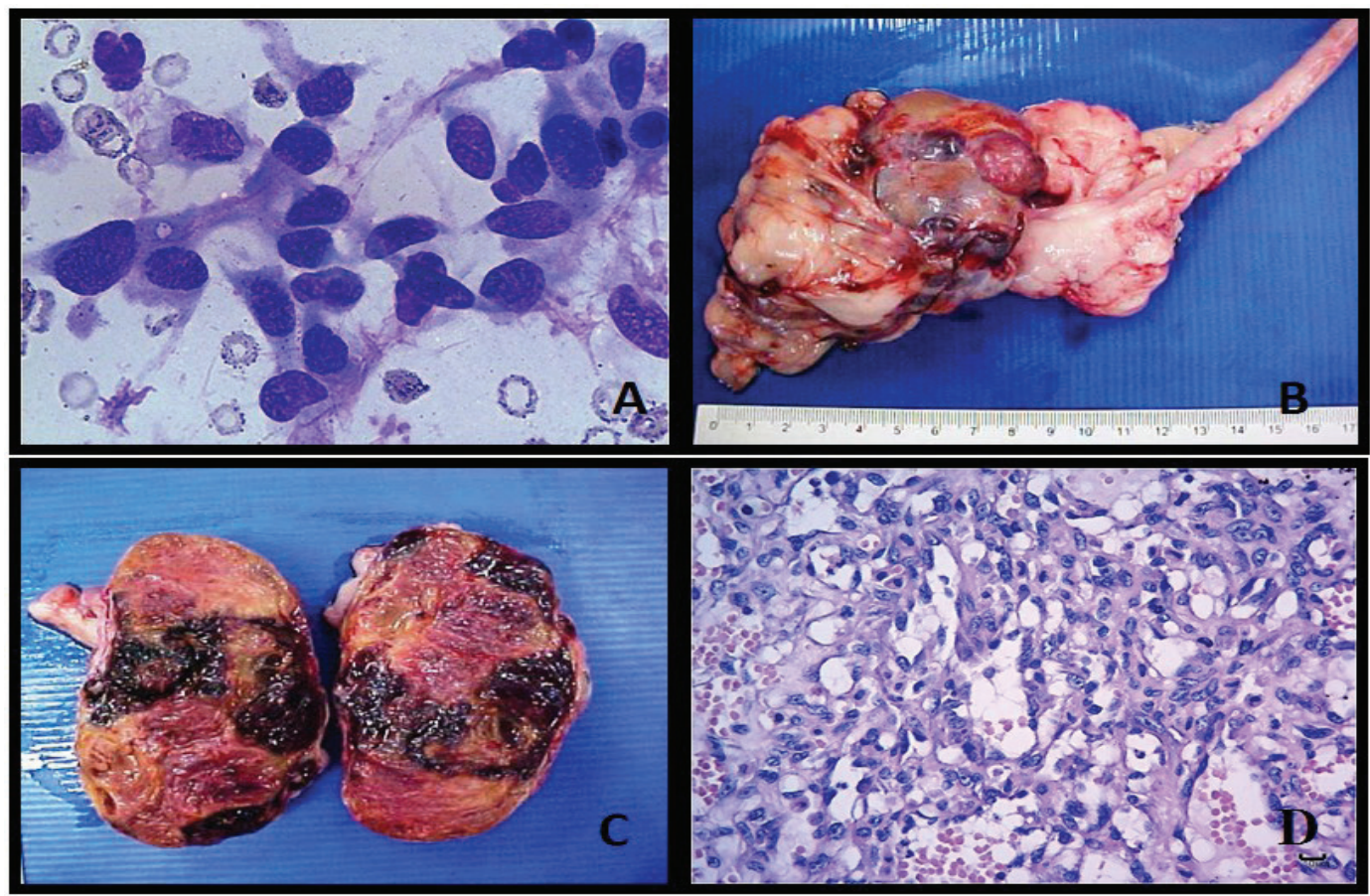

Source: Elaboration of the authors. 


\section{References}

BROWN, N. O.; PATNAIK, A. K.; MacEWEN, E. G. Canine hemangiosarcoma: retrospective analysis of 104 cases. Journal of American Veterinary Medical Association, Illinois, v. 186, n. 1, p. 56-58, 1985.

ERDEM, V.; PEAD, J. Hemangiosarcoma of the scapula in three dogs. Journal of Small Animal Practice, Oxford, v. 41, n. 10, p. 461-464, 2000.

GOLDSCHMIDT, M. H.; HENDRICK, M. J. Tumors of the skin and soft tissues. In: MEUTEN, D. J. (Ed.). Tumors in domestic animals. 4. ed. Iowa: Blackwell Publishing Company, 2002. p. 55-118.

GROSS, T. L.; IHRKE, P. J.; WALDER, E. J.; AFFOLTER, V. K. Vascular tumors. In: GROSS, T. L.; IHRKE, P. J.; WLADER, E. J.; AFFOLTER, V. K. (Ed.). Skin diseases of the dog and cat. Iowa: Blackwell Science, 2005. p. 735-753.

KLEIN, M. K. Tumors of the female reproductive system. In: WITHROW, S. J.; VAIL, D. M. (Ed.). Withrow \& MacEwen's small animal clinical oncology. 4. ed. St. Louis: Saunders Elsevier, 2007. p. 610-618.
LIPTAK, J. M.; DERNELL, W. S.; EHRHART, E. J. Retroperitoneal sarcomas in dogs: 14 cases (1992-2002). Journal of American Veterinary Medical Association, Illinois, v. 224, n. 9, p. 1471-1477, 2004.

LIPTAK, J. M.; DERNELL, W. S.; WITHROW, S. J. Haemangiosarcoma of the urinary bladder in a dog. Australian Veterinary Journal, St Leonards, v. 82, n. 4, p. 215-217, 2004.

OKSANEN, A. Hemangiosarcoma in dogs. Journal of Comparative Pathology, London, v. 88, n. 4, p. 585-595, 1978.

SFORNA, M.; BRACHELENTE, C.; LEPRI, E.; MECHELLI, L. Canine ovarian tumors: a retrospective study of 49 cases. Veterinary Research Communication, Philadelphia, v. 27, p. 359-361, 2003. Supplement 1.

THAMM, D. H. Miscellaneous tumors. In: WITHROW, S. J.; VAIL, D. M. (Ed.). Withrow \& MacEwen's small animal clinical oncology. 4. ed. St. Louis: Saunders Elsevier, 2007. p. 785-823.

TYLER, R. D.; COWELL, R. D; MEINKOTH, J. H. Cutaneous and subcutaneous lesions: masses, cysts, ulcers, and fistulous tract. In: COWELL, R. D.; TYLER, J. H.; MEINKOTH, J. H. (Ed.). Diagnostic cytology and hematology of the dog and cat. 2. ed. St. Louis: Mosby, 1999. p. 20-51. 
